\title{
The Albanian Reform in the Institutions of Justice and Its Impact on the Integration of Albania in the European Union
}

\author{
Dr. Yllka Rupa \\ Faculty of Law, "Luigj Gurakuqi” University of Shkoder
}

\author{
Doi:10.5901/mjss.2017.v8n1p196
}

\begin{abstract}
The reform in the institutions of law consists of a complexity of issues that aim at the establishment and functioning of a transparent, independent, professional and efficient system that ensures justice. Implemented in accordance with the strict condition of the European Union imposed on Albania, within the integration framework, the reform targets the reorganization and full reconstruction of the key instruments of the justice system. In this paper, there will be specific analysis of the issues related with the establishment and functioning of the main institutions of the administration and monitoring of the judicial power, constitutional and legal changes because of implementation the reform, as well as the role of the international structures, seen in the function of monitoring the implementation of the reform.
\end{abstract}

Keywords: reform, judicial power, court, prosecution, verification

The judicial system and its role in guaranteeing the state of law The independence of the judicial power is constantly being seen as the prerequisite to guarantee the state of law. ${ }^{1}$ The Albanian state build on the principles of the democratic way of state construction, it has long entered the irrevocable path of building the governmental, lawmaking and judicial institutions, in accordance to the western democratic models. Being a relatively underdevelopment state, considering here the legislative reforms as well, an important focus is given to the adaptation and harmonization of the normative corpus with that of the European Union countries, especially in the fields that have a direct connection with respecting and guaranteeing the state of law. After singing the agreement on stability and association with the European Union, the Albanian Government had to put a lot of effort into the construction and implementation of strategies through which it would implement the obligations that were set upon from Europe, in relation to the integration process. This process seems everlasting for Albania due to several factors from which the political one was decisive for slowing down the reforms. But which were the urgent obligations to be implemented so that Albania would be part of the European Union? The new legal framework, as the new state inherited old laws that did not fit with the new system of the state organization. Consolidated institutions that would monitor the implementation of the law and overall independent and efficient bodies in the framework of providing justice. The integration process that accompanied Albania these last 10 years, was followed by the passing of news laws related to the key field of the implementation and protection of the fundamental human rights and freedom. Several other reforms in the field of justice are part of this reform which were accompanied with the creation of completely new institutions for the Albanian territory, whose efficiency and activity was not subtle. As we know, democratic countries are established on principles which guarantee first of all the respect of the rights and freedom that pertain to each individual, or his/her natural rights. From these principles, two are the most important, the division of powers as well as the legality in the organization and functioning of the state and its authorities. This way the state is bound to lawfulness, it bases its activity on the judicial norms and therefore the representative authorities of the state act in compliance with the rules of law. On the other side, the principle of power division, guarantees effectivity especially in controlling the implementation of the law. It is the courts that control the implementation of the law, not only in the activity of the private implementation of the law, but from the state authorities as well. The judicial power is considered as the most important cog that ensures the principles of a judicial and democratic state, and the current state is being evaluated as the state of law today, seen exactly from the point of the view of the efficiency of the judicial power. The reforms in the Albanian justice system didn't begin in the last two years. The judicial system was earlier reorganized in many of its aspects. Moreover, the creation of special courts and laws for the Administrative Court are part of an indisputable process in the judicial system. However, the judicial system in Albania had an urgent need for a full reform, due to visible problematics reflected in way justice was provided. The European

1 Opinion Nr.1(2001) para 10, Recommendation/Rec(2010)12 para 3,11, CCJE Magna Charta of the Judges 
Union emphasized the judicial reform as being a primary condition for the integration of Albania, due to handicaps encountered in the implementation of the law as a result of several factors from which the control of judicial power from the politics and corruption was seen as the most problematic. The reform in the justice system came as a need to change the condition of the judicial bodies. But which are the main problematics revealed in the recent years in the judicial system bodies?

The identification of the problematics in the judicial system were seen as important in the aspect intervening specifically in these issues. They are related with the quality in which justice is provided, the independence of the judicial power and what is more important the absence of the public trust in the judicial bodies. The quality in which justice is provided is related with the moral and professional integrity of the judge. Guarantees for the quality of the justice provision as well as in the existing normative acts are presented in a high level, which is where rigorous conditions are imposed for the appointment in the judicial bodies. Likewise, promotion in the workplace and career of the judge are conditioned in a way as to avoid the appointment in supreme courts of people with inadequate professional career. However, the question is what threatens the provision of justice and in this context there should be taken into account the way judges are appointed and the structure of the main bodies that manage their movement into the judicial system. In accordance to this, there has been highlighted the reorganization of the High Council of Justice and a part of its members come from the Executive Council and they are even in leading positions as the case of the Minister of Justice. This body has not only changed completely, but the way it functions as the body that controls the movements in the judicial system, has changed too. The political control on the judicial bodies is a very controversial topic in Albania and it has been present in many reports of the international authorities. Personal gains through corruptive affairs are definitely present due to the lack of the proper function of the system. These two problematics have led in the public mistrust in the judicial institutions. The negative image of the judicial comes as a result of the involvement in the system of people whose concept for material gains goes beyond the demand for a positive image of the judges' personality. The quality of justice provision and the clean image of the judge are the two most controversial issues and that encounter a rigorous regulation with the reformative changes in the system. The careful verification of the judge's image, mainly focused in the moral and professional integrity is a well-treated issue in the changes in the constitution and constitutes a big step ahead in the effort of providing justice in a quality way. Overall, this process will have a positive impact on the image alternation of the Albanian Justice.

\section{Some of the Most Important Aspects of the Changes in Constitution}

The reform in justice lead to a new regulation in relation to the function and organization of the main constitutional bodies, that bear the competence of exercising the judicial power. Likewise, there were changed in the provisions that regulate the competences and the intervention of other constitutional bodies in the organization of the justice system. The most important part of the reform is definitely related with the constitutional changes and precisely with the intervention of the main constitutional bodies in the act of ensuring justice. The problematics encountered in practice have often been a reflection of malfunction of the constitutional framework in relation to the institutions of the justice system. Therefore, the Constitution of the Republic of Albania has been revised three times since its entrance into force in 1998. The experience of these last years has shown that the changes in the constitution, especially those of the 2008, have had a negative influence in the organization and function of the justice system. ${ }^{2}$ As a result, the new changes in the Constitution bring about innovation in the organization of the new role of the constitutional bodies in the implementation of the judicial duties as well as the guarantee of an independent judicial power. The role of the President consists in keeping the balance in the justice institutions and ensuring a coherent collaboration in between the constitutional bodies that organize the judicial system. This is accomplished through that competences that were given to the president, mainly in the process of the appointments of crucial exponents of the judicial system, and those of the justice institutions. Based on this, the way the president is elected and his role in implementing the constitutional functions related to the judicial system, occupy an important part of the altered package. The justice reform also makes possible a full reorganization of the creation, function and content of the main bodies that administrate the judicial system. The High Council of Justice, the Prosecutor General, the Supreme Court as the basic institution that are related to justice, have been the most effected organs of the reforming process. The full reorganization of them, in content and competences, aims at ensuring the independence of the judicial system, effectivity in providing justice, as well as impartiality and professionalism from the judges. The very important institution that monitors the implementation of the Constitution as well as the implementation of the constitutional principles from the main state institutions and at the same time monitors the judicial system, is the

${ }^{2}$ Reform Strategy in the Justice System pg.5, Tirane 2015 
Constitutional Court. In compliance with the constitutional provisions, it is the main instrument of analyzing the courts activities in their function of exercising the principle of legality in organizing adequate legal processes that guarantee the respect of the human rights and freedom. Moreover, the reform foresees a re-dimensioning of this body, by predicting new rules in relation to the appointment of the Constitutional Court members as well as their length of tenure. The independence, impartiality and efficiency of the Constitutional Court, are premises of the implementation of the constitutional principles and the constitutionality of the law-making process. In this context, interventions in the constitution which have affected not only the institutions of the Constitutional Court, but all the constitutional institutions that have to do with the judicial power, aim at determining stable rules that ensure the longevity of the constitutional provisions. In order to create a new judicial system that would ensure the human rights and freedom, it is necessary the creation of the new institutions that monitor the judicial bodies. A huge importance was given to the institution of work inspection in the justice system, which comes with a complete new organization. Likewise, the Prosecutor General and the Prosecution body, as constitutional institutions have a form of organization and function almost completely new. The role of the Prosecutor General starts with the functions that are given to him from the Constitution but also from the way of appointment and length of tenure, the role becomes more present in the implementation of duties of the judicial system. Therefore, the constitutional changes evaluate the role of the prosecution in providing justice and carefully determine the criteria for the appointment of the Prosecutor General.

\section{The Role and Competences of the President of the Republic under the Constitutional Changes}

The role of the President of the Republic is significantly present in the reformatting of the bodies of justice and as we mentioned it is more visible in balancing the judicial institutions with the other powers. His interventions in setting up and organizing the institutions, the appointment of the members of the Constitutional Court, the Supreme Court and High Administrative Court, are determined through the competences expressed in the constitution which have definitely strengthened the influence of the highest state body in strengthening the independence of the judicial power. Regarding the Constitutional Court, the appointment of the judges in the Constitutional Court in particular, the President is vested with the competences to appoint the three judges. With the constitutional changes, this court has a new organization in relation with the way of the appointment of the judges, the competences, the length of the tenure etc. It consists of 9 members, three of them appointed from the President, three from the Assembly, and three from the joint meeting of the Supreme Court and Supreme Administrative Court. ${ }^{3}$ As a result, the intervention of the President in the content of the Constitutional Court is evident, for as long as he has the function of appointing the three judges. This fact constitutes a further insurance in guaranteeing the impartiality of this body as well as not making it possible to be controlled from the legislative or executive courts. Despite this, the presidential competences do not risk at strengthening the influence of the President in the Constitutional Court, as the appointment is not related with the exclusive appointment of the president himself, but with the selection from a list of candidates, compiled from the Appointment Council in Justice. The president also has the right to monitor the Constitutional Court. Anytime the President notices inconsistencies of the normative acts with the constitutional principles or severe constitutional offences form the institutions of the three powers, the president can address the Constitutional Court. Regarding the Supreme Court and the Administrative Court, the President has the competence of appointing the judges, but different from what we mentioned in the Constitutional Court, the competences here are wider, as the President can reject the proposals set forward. The Constitutional Law states that the appointment of the judges in the Supreme Court and Supreme Administrative Court is carried out from the President of the Republic with the proposal of the High Judicial Council, for a 9-year tenure without the possibility of reappointment. The President within 10 days from the proposal appoints the judge or he can disagree and reject the proposals of the High Judicial Council, by presenting his reasons and arguments for each case. ${ }^{4}$ The President's decree for the refusal of the proposals from the High Judicial Council loses its power if most of its members vote against it. In this case, and when he President does not express himself, the candidate is considered as appointed and starts his job while respecting the time-period set by the constitutional law that is 15 days form the day of the decision-making from the High Judicial Council. Considering the way in which the appointment of the judges is organized in the high instances of the judicial power, we notice that the role of the President of the Republic is just selective in the sense of the moral and professional integrity of the individuals proposed for high levels of the judicial system. His intervention in the form of refusal happens only in cases when the

\footnotetext{
${ }^{3}$ Law Nr.76/2016 "For some addition and changes in Law Nr.8417, date 21.10.1998, "The Constitution of the Albanian Republic", changed.

${ }^{4}$ Law Nr.76/2016 "For some additions and changes in Law Nr.8417, date 21.10.1998, "The Constitution of the Albanian Republic", changed
} 
candidate does not meet the qualification criteria or selective conditions according to the law. However, it is the majority of the High Council of Justice that decides on the appointment and the President's decree loses its power.

\section{The Reform in Justice Creates Two New Institutions}

The High Judicial Council and the High Prosecution Council. The High Judicial Council is the institution which is entrusted with the insurance of independence and efficiency of the judicial power. There are jurists in its consistence that come not only from the judicial, but also outside it, on the condition that they have high moral and professional integrity, though. So, the High Judicial Council has a heterogeneous consistence regarding the fields the members come from. They should have at least 15 years of experience in the profession and they should also be well-known names in their respective fields. Times ago, it was the High Council of Justice who had wide competences in the movement of the judges within the systems, as well as with the appointment of the new ones. Besides the members that were selected from the judicial board in three levels and the judges that were elected from the Assembly, the High Council of Justice was also composed of representatives from the executive who because of the ex officio duty, were part of those structures, even in leading positions. ${ }^{5}$ The presence of the representatives that came from politics was clearly noticeable, and even determining in cases when the Minister of Justice led the High Council of Justice. This caused for many verdicts taken from this body regarding the movements in the justice system, to be highly politically influenced. The revision of the content and of the way the members are selected, became urgent because of the factice control from politics. This phenomenon was of course related with the way the appointments were done in the High Council of Justice as well as the influence of it. The reform of the justice system through the changes in constitution, would soon begin with the reformation of the bodies that will be responsible for the appointment of judge. This time, it was carefully handled the situation of the content of the judicial body, to be completely devoid of political influence, as it was also set as a primary condition in selecting the candidates. The constitution determines that the members of the High Judicial Council must have an experience of more than 15 years in the profession, they mustn't have held political positions in the public administration or leading positions in a political party in the last 10 years before applying for the position. The legal initiatives to create an independent body for the appointment, evaluation, promotion, and especially the movement of the judges in the justice system, is a foundation stone to accomplish one of the most difficult challenges of a democratic state, accomplishing the independence of the judicial power. This absence of independence in the appointment of the judges, has been one of the most controversial and shocking issues in the justice system. The selections without criteria and completely political in the High Council of Justice, have absolutely favored the appointment in very important positions of the Judicial system, subjects with a lack of high professional profile, who being in that position have become guaranteed instruments for exercising and protecting the political corruptive affairs. The representative of an international organization would say that "In Albania, the independence in appointments for the Supreme Court and Constitutional Court has not been guaranteed yet and the current system requires the revision to avoid the constant for political claims". ${ }^{6}$ The importance of the appointment body and judicial administration is definitely a must, however, for an efficient functioning there is the need of a coherent adjustment in all the cogs that participate in the creation of an independent judicial. The reform in the Albanian Justice is definitely the biggest reform that the state institutions have ever done. Approved with a full consensus from all the political wings, it is seen with the eye of a future independent and transparent power. Considering the fact that the reform touched the constitutional dispositions, and because of the need for intervention in reorganizing the constitutional bodies that administrate justice, it was shown special care to ensure the stability and flexibility in the new changes. Therefore, the High Judicial Court has been modeled as the only responsible authority to control the judges' activities, the appointment, firing and evaluation of the moral and professional integrity of them. It is the authority that has the responsibility to control the activity of the three instances of the judicial system in the context of law implementation, high performance and impartiality. These modalities should not be seen as separated from the other bodies in the justice field, but as a guarantee of coherent collaboration in between them. Another innovation of the reform is the way of organizing the investigation of the judges' activities.

The High Council of Justice is the responsible body assigned by law to verify the complaints, investigations on offenses and starting the disciplinary procedure towards the judges and prosecutors of all levels, members of the High

\footnotetext{
${ }^{5}$ Law Nr. 8417, date 21.10.1998, "The Constitution of the Albanian Republic"

${ }^{6}$ Cheirie Booth Blair, "The importance of judicial independence for a free and fair judgement", Tirane 2012
} 
Judicial Council, members of the High Council of Prosecutors. ${ }^{7}$ This body has in its competence the institutional investigation of the courts and the prosecution offices primarily in relation to the notified offenses having been completely against the law and are presented in the form of a complaint for a proper trial. The High Council Inspector is appointed for a nine-year mandate from $3 / 5$ of the members of the Assembly without the right of being reelected, from the most notable jurists with at least 15 years of experience in their profession with high professional and moral integrity. ${ }^{8}$ The law foresees the inability of a person to be appointed if he has carried political functions in the public administration, or leading positions in a political party during the last 10 years before his candidacy. The availability of the judicial institutions, which consist of people achievements in their careers is one of the biggest challenges in the reform of the justice system. The way the justice bodies are administered and the selective process of the judges are certainly very important parameters to guarantee a judicial system that respects the human fundamental rights and freedom. The Constitution of Albania sanctions the principal of independence of the judge to exercise his functions in providing justice. As a result, the judicial administration has been considered as a structure that is in the service of this principal and creates the proper premises in fulfilling the final mission for a fair, impartial and qualitative trial. The judicial administration should never be used as a pretext to control the content of the individual judicial verdicts. ${ }^{9}$ The new constitutional changes have made clear the institutional competences in administrating justice by also respecting the main principals of the state of law in dividing the powers and exercising legality of their activities. The reform that touch the constitution are usually dictated from the urgent need. They are products of long consultations, especially in high levels of investigation and claim the creation of stable, coherent and productive foundations for the cases they treat. As such the reform in the Albanian justice system is the product of a long consulting process which set strong foundation in the constitutional law without forgetting several aspects tightly related to it. A range of laws has been approved and will be approved in the framework of implementing the reforms, despite the special terrain and problematics. The Albanian legal system continues to be in transition, influenced from different legal systems, especially European. ${ }^{10}$ The reform predicts new ways of controlling and evaluating "purity of the image" for high officials of the judicial bodies. As cited above, as essential criteria to promote the judges and prosecutors' careers, there are several elements that have to do with professionalism, ethics, behavior, trustfulness and full integrity from the professional and moral point of view. The law predicts the creation of a new re-evaluation system aiming at guaranteeing the function of the state of law, the independence of the judicial power, as well as reestablishing people's trust in the institutions of this system ${ }^{11}$. The re-evaluation is predicted to be exercised based on the principals of proper process and by also respecting the fundamental rights of the subject being evaluated. The vetting process involves all the judges, including here judges of the Constitutional Court, Supreme Court, all the prosecutors as well as other officials that because of their positions are subjected to ex officio re-evaluation. The ways of controlling the judicial staff besides being delicate due to conserving the untouchability of some principles that are organically related with the function, are presented as complex for many reasons. The court, because of the function it has, is the power that was given the exclusiveness of controlling the two other powers related with the implementation of the legality principal in exercising their functions. Likewise, the judicial power exercises its activity in an independent way. The independence of the judicial, is related in a way with the respect and implementing the decision making process as a product of a fair and professional trial, led from the truth in insuring social justice. For as long as the justice system achieves to guarantee high values that increase the trial standard, the judges' authority and overall the trust in people, the verification process has difficulty in being implemented. However, based on what we said above, the Albanian judicial system is significantly far from the standards set on democratic states for an independent and reliable system. The control of the judges, among other things, is predicted to have some functions. First of all, it helps in improving the professional quality of the authorities that provide justice and secondly, fulfilling the ethical and moral criteria. The vetting or the process of verifying the members of the justice institutions does not threaten in essence their independence in exercising their duties. It is a transparent process that aims at constructing a system on the basis of meritocracy literally. In the professional aspect, the judges are independent in exercising their functions required by law and the court is the final word when it comes to solutions demanded in different situations. In this aspect, it is the doctrine the one that offers an incomparable judge for the judicial functions because of being free and diverse, it offers solutions and not impositions,

\footnotetext{
${ }^{7}$ Law Nr.76/2016 "For some additions and changes in Law Nr.8417, date 21.10.1998, "The Constitution of the Albanian Republic", changed, Article 174, point $b$

${ }^{8}$ Law Nr.76/2016 "For some additions and changes in Law Nr.8417, date 21.10.1998, "The Constitution of the Albanian Republic", changed

${ }^{9}$ Cheirie Booth Blair, "The importance of judicial independence for a free and fair judgement", Tirane 2012

10Nuni. A, "Law, Justice and us, in 20 years of reflection" Tirane 2012

${ }_{11}$ Article 179/b, Law Nr.76/2016 "For some additions and changes in Law Nr.8417, date 21.10.1998, "The Constitution of the Albanian Republic", changed
} 
it strengthens and does not threaten the independence..$^{12}$ Outside of this aspect, there is the need to see the reevaluation process of the judicial staff. Sanctioned with constitutional dispositions, this controlling aspect is predicted to be implemented through qualified bodies in accordance with the constitutional and legal predictions. The reevaluation system is more or less a similar system with that of the administrative judgement, where besides the scrutiny from the assigned organs and the constitution, on the evaluation of the judges and prosecutors, they have the right to contradict the evaluation process in a higher body through appealing procedures. ${ }^{13}$ The reevaluation is carried out from Independent Qualification Commission, whereas the appeals are reviewed from the Appealing College in the Constitutional Court. This is a long process towards success which is related with several other factors. However, it is an important step and the most controversial in the justice reform that limits the establishment of the independent judicial power in Albania

\section{Conclusions}

The judicial system in Albania has often been presented as a weak and corrupted system. This comes as a result of gaps encountered in the implementation of justice as a consequence of several factors among which are the control of the judicial power from politics and corruption which are seen as the most problematic.

The reform in justice was a necessity to change the condition of the organs in the justice system and a primary condition for the integration of Albania in the European Union

The constitutional changes assign new organs to administrate the judicial power. A special care was given to the determination of the criteria for the judges and prosecutors' appointment. New structures have been created to reevaluate the careers of subjects in the justice system.

The main purpose of the reform is the increase of the independence in the judicial power and its liberation from politics and corruption. In this framework the entire judicial staff will go through a process of moral and professional testing. The vetting or the process of verifying the members of the justice bodies, does not threaten their independence in exercising their duties. It is a transparent process that aims at constructing a system based on meritocracy.

\section{References}

Ledi Bianku, 'Who judges the judges?", Tirane 2012

Cheirie Booth Blair, "The importance of judicial independence for a free and fair judgement", Tirane 2012

Nuni. A, "Law, Justice and us, in 20 years of reflection" Tirane 2012

Law Nr.76/2016 "For some additions and changes in Law Nr.8417, date 21.10.1998, "The Constitution of the Albanian Republic", changed

Law Nr. 8417, date 21.10.1998, "The Constitution of the Albanian Republic"

12 Ledi Bianku, 'Who judges the judges?", Tirane 2012

${ }^{13}$ Article 179 , Law Nr.76/2016 "For some additions and changes in Law Nr.8417, date 21.10.1998, "The Constitution of the Albanian Republic", changed 